\title{
Silica treatment technologies in reverse osmosis for industrial desalination: A review
}

\author{
Yong-Min Park' ${ }^{1}$ Kyung-Min Yeon ${ }^{2}$, Chul-hwi Park ${ }^{1^{+}}$ \\ ${ }^{1}$ Department of Environment Engineering, The University of Seoul, Seoul, Republic of Korea \\ ${ }^{2}$ Engineering Center, Samsung C\&T Corporation, Tower B, 26, Seoul, Republic of Korea
}

\begin{abstract}
Reverse osmosis (RO) is the main process of current industrial desalination, and its performance is affected by the quality of water source. Natural water contains a certain level of silica, which is originated from metal silicate in the earth crust. Due to its complexity, silica fouling is difficult to control, which often causes less efficient design of RO system for safe operation. In the present work, we review the current state of silica treatment technology in RO desalination. Silica chemistry is investigated in standpoint of the scale formation mechanism among multiple forms of silica species and its synergistic interaction with other foulants such as organic matter. Then, pretreatment methods to remove silica in the $\mathrm{RO}$ feed water are outlined. They include softening/coagulation, seed precipitation/aggregation, tight ultrafiltration, ion exchange, adsorbents media, and electro coagulation. We finally highlight the mitigation of RO fouling under silica rich conditions, whose concept can be implemented in different ways of antiscalant dosing, high/low $\mathrm{pH}$ operation, and intermediate softening of the $\mathrm{RO}$ concentrate, respectively. This review will provide comprehensive information and insight about the optimal operation of industrial RO susceptible to silica fouling.
\end{abstract}

Keywords: Industrial desalination, Pretreatment, Recovery rate, Reverse osmosis, Silica fouling

\section{Introduction}

Water is one of the major and indispensable resources in many industries. Furthermore, some water-intensive industrial segments require a vast amount of pure water. They typically include microelectronics, pharmaceutical, mining, oil/gas, refining/petrochemical, power generation, pulp/paper, and food/beverage. Accordingly, industrial desalination has emerged as one of the most important issues in the water business over the past decades. The general desalination system consists of pretreatment, reverse osmosis (RO) filtration, and post treatment. In this configuration, RO is the core process assuring water quality criteria for industrial usage.

Both the design and operating performance of the RO system are affected largely by water source quality. Silicon is the element which is the second most abundant in the crust of the earth by mass. Therefore, natural water sources usually contain a certain level of silica, from 1 to $40 \mathrm{mg} / \mathrm{L}[1,2]$. In some geographic areas, its concentration can reach up nearly to $100 \mathrm{mg} / \mathrm{L}$ [3-5].

As RO operation proceeds, the silica level in the concentrate stream increases and often reaches saturation, which can cause

This is an Open Access article distributed under the terms of the Creative Commons Attribution Non-Commercial License (http://creativecommons.org/licenses/by-nc/3.0/) which permits unrestricted non-commercial use, distribution, and reproduction in any medium, provided the original work is properly cited.

Copyright (C) 2020 Korean Society of Environmental Engineers deposits of silica, or precipitation of metal silicates on the membrane surface (Scaling). Silica fouling is very difficult to remove from RO membrane, and eventually leads to performance deterioration such as permeability loss and premature system shutdown [6]. Although strong cleaning chemicals like ammonium bifluoride $\left(\mathrm{NH}_{4} \mathrm{HF}_{2}\right)$ and hydrofluoric acid $(\mathrm{HF})$ can be used to remove silica fouling, the use of harsh cleaning chemicals brings the risk of equipment damage and environmental concerns [7]. As a result, $\mathrm{RO}$ plant is often forced to operate less efficiently. That is to say, the recovery rate of RO system is decreased to maintain the silica level in the concentrate stream below its saturation point, depending on operating $\mathrm{pH}$ and temperature. The decreased recovery rate means excessive feed water requirement and more wastewater discharge for the same water production capacity.

This literature study aims to provide comprehensive information on how to effectively control silica scaling in RO desalination. Silica in water has multiple forms of dissolved, polymeric, colloidal, and particulate (e.g. sand), respectively. Each silica formulation has different physicochemical properties and is involved in the scale formation via various mechanisms of monomeric deposition,
Received August 22, 2019 Accepted December 31, 2019
${ }^{\dagger}$ Corresponding author
Email: chpark@uos.ac.kr
Tel: +82-6490-2863
ORCID: 0000-0002-0803-6353 
polymerization, and particle accumulation [8]. In field-scale practice of RO desalination plant using natural water, organic fouling as well as inorganic scaling significantly constraints the RO performance [9, 10]. Silica chemistry is investigated to understand the complex scaling phenomenon summarizing scale formation mechanism among multiple forms of silica species and its synergistic interaction with organic fouling. Next, the current practices of silica treatment techniques are reviewed. We classify the silica treatment into two categories of pretreatment and scaling prevention. Silica concentration in RO feed water can be lowered by using various pretreatments. We focused on the operation principle of each pretreatment which determines the silica removal efficiency. Mitigation of silica scaling in RO system can allow the stable operation under silica oversaturation. Process configuration and enhancement of recovery rate is discussed presenting field case of industrial application. After brief summary of currently available options, we discuss technical trends to gain insight into the optimization of an industrial RO system.

\section{Material and Methods}

In this section, we review silica chemistry in standpoint of its multiples forms in water, solubility, and scale formation, which gives the basic overview of both silica fouling and its control techniques.

\subsection{Classification of Silica Species in Water}

Silica exists in either crystalline or amorphous form [3]. Amorphous silica is classified further as dissolved, polymeric, colloidal, and particulate. Silica in natural water comes from the dissolution of rocks and minerals (Eq. (1)). The main dissolution reaction is the hydrolysis of Si-O-Si bonds, resulting in production of silicic acid $\left(\mathrm{H}_{4} \mathrm{SiO}_{4}\right)$.

$$
x \cdot \mathrm{SiO}_{2} \text { (Solids) }+2 \mathrm{H}_{2} \mathrm{O} \leftrightarrow(x-1) \mathrm{SiO}_{2}+\mathrm{H}_{4} \mathrm{SiO}_{4}
$$

The dissolved silicic acid is also referred to as reactive silica. The term 'reactive' means that the silanol group (Si-O-H) reacts with ammonium molybdate $\left(\left(\mathrm{NH}_{4}\right)_{2} \mathrm{MoO}_{4}\right)$ to make a colored complex in quantitative determination [11]. Silicic acid is a weak tetravalent acid with acid dissociation constant $\left(\mathrm{pK}_{\mathrm{a}}\right)$ of 9.9 [5]. Silicic acid will remain in the monomeric state as long as its concentration is less than about $2 \mathrm{mM}$ [12]. When the concentration of silicic acid reaches a certain point, it begins to polymerize formulating polymeric, colloidal and particulate silica. The dimers, trimers, and other oligomers of silicic acid are generally referred to as polysilicic acid or polymeric silica. Amorphous silica polymerization occurs following a pattern of soluble silica unit breakdown and silicate anion growth into a larger macromolecule (Fig. 1(a)). The rate of silicic acid polymerization is strongly $\mathrm{pH}$-dependent. Briefly, it is fast in neutral and slightly alkaline solutions, and drops to a minimum at $\mathrm{pH}$ above 9.5 and below 6.5, respectively [5, 7]. Silica polymerization is also affected by the presence of other ions in water. Both calcium and magnesium increase the silica polymerization rate [13]. Magnesium hardness is more effective than calcium hardness $[7,12]$. The reactivity of polymeric silica is lower than that of silicic acid due to less silanol groups available. Polymeric silica with low molecular weight is considered to be unstable, and to have only a transient existence. Highly polymerized silica with a diameter of $5 \mathrm{~nm}$ or more are generally referred to as colloidal silica. In practice, the colloidal silica value is determined by the difference between the total and dissolved silica [5]. Colloidal silica is nonreactive and not necessarily removable by traditional filtration because of its extremely small size. Finally, particulate silica is usually defined as having a size larger than 1 micron (e.g. clays, silts and sand).

\subsection{Silica Solubility}

Silica scaling occurs when its concentration exceeds the allowable solubility. Crystalline silica has a low solubility of 5-6 mg/L, whereas the solubility of amorphous silica ranges from $120-150 \mathrm{mg} / \mathrm{L}$ at $25^{\circ} \mathrm{C}[12,14,15]$. In the water treatment system, the solubility of amorphous silica is affected mainly by temperature, $\mathrm{pH}$, and the presence of other ions [16]. The classic silica solubility graph were presented in Fig. 2(b). It is apparent that a rise in temperature substantially increases silica solubility. Silica solubility also depends on the $\mathrm{pH}$ condition because silicic acid is the weak acid. Briefly, its solubility is relatively constant up to a $\mathrm{pH}$ value of 9 , and shows a dramatic increase at a $\mathrm{pH}$ over 10 . The presence of multivalent cations such as hardness, iron, and aluminum reduces the apparent solubility of silica due to their interactions with the silicate anion. In particular, calcium and magnesium catalyze the polymerization reaction of dissolved silica. This means that higher concentrations of total hardness leads to a faster drop in dissolved silica level. Similar to cations, anions such as iodide, bromide, and chloride have been reported to reduce the silica solubility [16].

\subsection{Mechanism of Silica Fouling in RO Membrane}

Silica scaling mechanisms were depicted in Fig. 1(c). RO fouling relevant to silica scaling occurs mainly through deposition followed by polymerization, metal silicate precipitation, and accumulation of colloids/particulate formed in the bulk solution, respectively. According to the bench scale RO test by Semiat et al. [17], the silica saturation level in the bulk liquid phase affects the type of fouling mechanism. That is to say, silica scale deposition occurs by monomeric silica spies at low silica saturation levels. At high saturation level, however, silica deposition involves the colloidal particles, followed by some monomeric deposition. Surface property of RO membrane also has strong correlation with silica deposition. According to the study by Tong et al. [18], silica scaling in positive RO surface was more severe compared to negatively charged RO. This implies that silica deposition is affected by the charge interaction between silica spices and RO surface. After silica deposition onto membrane surface under neutral $\mathrm{pH}$, polymerization of dissolved silica occurs, building up amorphous layers which have morphology of non-uniform and impervious glass-like film. $\mathrm{pH}$ is one of the major factors in the precipitation of metal silicate. At $\mathrm{pH}$ close to the $\mathrm{pK}_{\mathrm{a}}$ of silicic acid, both silicate ions and polymeric silica can react with polyvalent metal ions such as calcium, magnesium, iron, manganese or aluminum to form insoluble metal-silicates scale [19]. It has also been reported that silica is precipitated even below its saturation when aluminum and iron coexist 
<smiles></smiles>
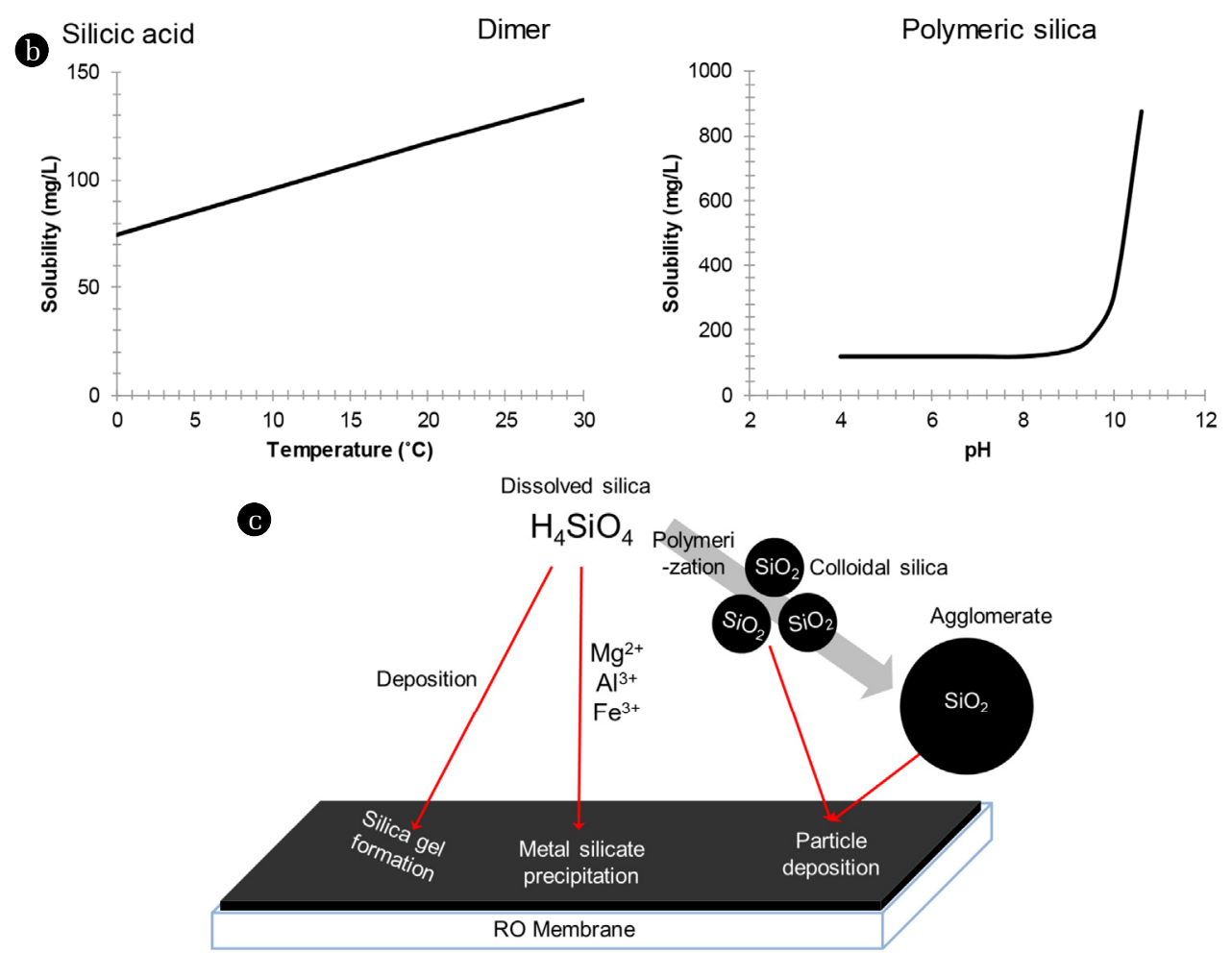

Fig. 1. Silica chemistry related to the scale formation. (a) Polymerization of silicic acid, (b) Solubility in water as function of temperature and $\mathrm{pH}$, (c) Inorganic fouling mechanisms on the RO membrane surface.

in the pretreated feed water. Practically, it was suggested that both aluminum and iron content of $\mathrm{RO}$ feeding water must be lower than $0.05 \mathrm{mg} / \mathrm{L}$ for safe RO operation [20]. Colloidal silica in bulk phase adheres to the membrane surface forming a thin layer, where other silica colloids bind through dissolution/precipitation over time. This particle accumulation develops typically gel-like and more uniform layer when compared to monomeric deposition. At the same time, calcium and magnesium, which facilitate colloidal silica formation, result in particulate deposition in addition to direct precipitation of monomeric silica [21].

Organic fouling and inorganic scaling are two primary RO fouling mechanisms. In that sense, interaction between silica species and organic components including proteins and polysaccharides have been studied to evaluate the fouling potential in RO desalination using groundwater and secondary wastewater effluent [22]. Kimura et al. have reported that coexistence of silica and organic components in the effluent from membrane bioreactor largely decreased the flux in RO system compared to individual organic fouling or inorganic scaling [23]. Qauy et al. [24] examined combined effect of organic fouling and silica scaling using model proteins of bovine serum albumin (BSA) and lysozyme (LYZ). Both model proteins demonstrated synergistic flux decline. However, each associated mechanism seems to be different according to intrinsic properties of protein. For instance, interaction with negatively charged BSA and silicic acid formed protein-rich aggregates, whose attachment developed compact and dense fouling layer. The presence of divalent ion such as calcium and magnesium participated in the precipitation of BSA-silica. On the other hand, positively charged LYZ protein promoted to silica precipitation with relative higher silica contents. In summary, the presence of organic foulants can expedite the silica scaling in RO system, suggesting additional research challenge for silica fouling against feed water with organic contents [24].

\subsection{Chemical Cleaning of Silica Fouling}

As previously mentioned, silica scaling can be chemically removed by using ammonium bifluoride and hydrofluoric acid. However, these harsh chemicals also have the risk of membrane damage and disposal of hazardous chemical waste after cleaning. During commercial operation of RO plant, cleaning-in-place (CIP) is periodically performed to recover the permeability of RO membrane. In general, silica fouling layers can be removed using caustic based product such as sodium hydroxide at the maximum $\mathrm{pH}$ allowed 
by the membrane manufacturers. Removal of silica fouling under alkaline CIP condition can be explained by that silica dissolution is catalyzed by hydroxide ion. However, removal of silica scale from RO membrane surface using alkaline CIP generally takes considerable time, which inevitably increases the capacity of stand-by RO system for continuous water supply.

\section{Pretreatment for Silica Removal}

Reducing silica concentration in the feed water by pretreatment can be a simple and effective approach to mitigate silica scaling in subsequent RO system. In this section, we review currently available silica pretreatment options, including their principles and application issues.

\subsection{Softening and Coagulation}

Both dissolved and colloidal silica can be removed from the water stream by adsorption on insoluble metal hydroxides and coprecipitation with soluble metals. In practice, softening [1, 3, 7, 25-28] and coagulation [29-35] are capable of removing silica based on this principle.

Two mechanisms can be responsible for silica removal in the softening process (Fig. 2). One is silica adsorption into $\mathrm{CaCO}_{3}$ and $\mathrm{Mg}(\mathrm{OH})_{2}$. At a constant hardness condition, $\mathrm{Mg}(\mathrm{OH})_{2}$ was reported to be more effective in silica adsorption than that of $\mathrm{CaCO}_{3}[9,12]$.

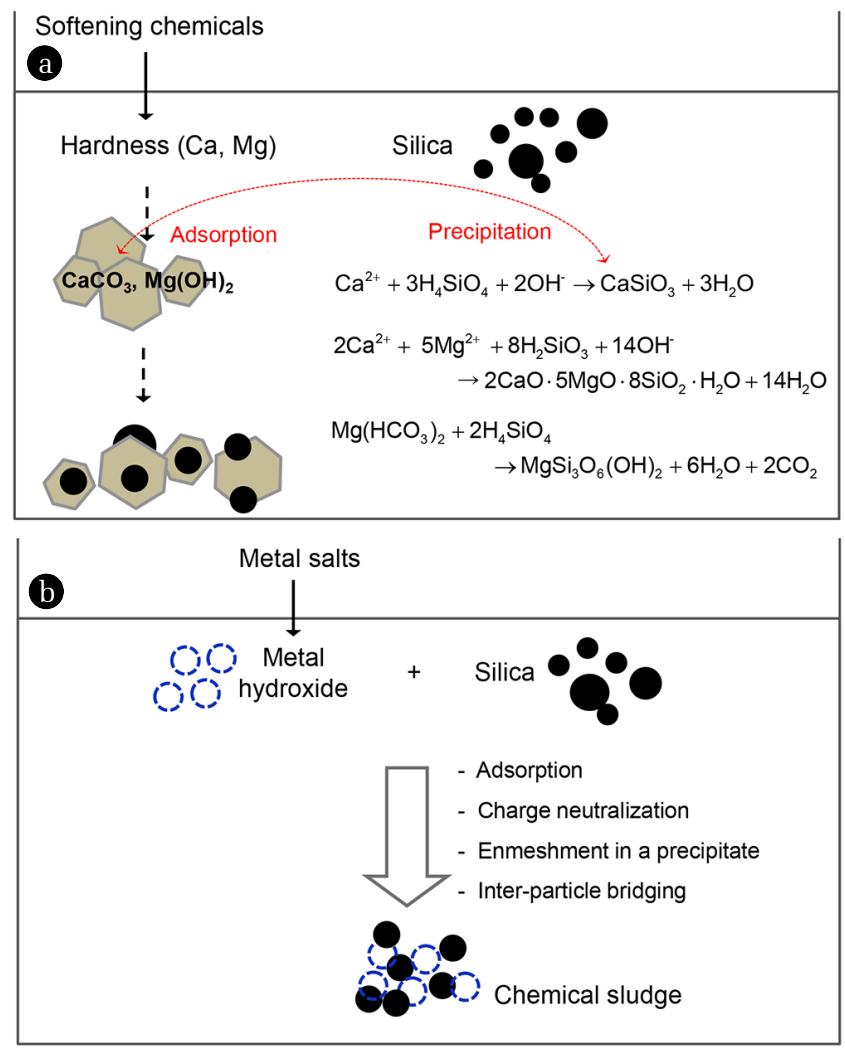

Fig. 2. Schematic illustration of silica removal by (a) Alkaline softening and (b) Coagulation.
The other is the formation of silicate precipitates with different stoichiometry. Some frequently quoted reactions of silicate precipitation are depicted in Fig. 2(a). However, they are likely to be oversimplifications because the actual precipitates are often more complex [36]. Silica removal efficiency by softening depends on solution $\mathrm{pH}$ condition. For example, the optimal $\mathrm{pH}$ for silica adsorption onto $\mathrm{Mg}(\mathrm{OH})_{2}$ was found to be around 10-11 [7]. Under adequate $\mathrm{pH}$ adjustment, silica removal efficiencies of more than $95 \%$ have been reported [36, 37]. Softening is feasible when raw water contains a certain level of hardness to induce enough amount of $\mathrm{Mg}(\mathrm{OH})_{2}$. Magnesium compounds and coagulants can be added to improve the overall silica removal efficiency [38-40]. To enhance silica removal efficiency in softening, sodium aluminate $\left(\mathrm{Na}_{2} \mathrm{Al}_{2} \mathrm{O}_{4}\right)$ can be used [1]. The reactions of sodium aluminate are summarized in Eq. (2) and (3). Sodium aluminate reduces magnesium hardness without increasing calcium hardness. In addition, formation of aluminum hydroxide $\left(\mathrm{Al}(\mathrm{OH})_{3}\right)$ aids silica removal from the treated water.

$$
\begin{gathered}
\mathrm{Na}_{2} \mathrm{Al}_{2} \mathrm{O}_{4}+4 \mathrm{H}_{2} \mathrm{O} \rightarrow 2 \mathrm{Al}(\mathrm{OH})_{3}+2 \mathrm{NaOH} \\
\mathrm{Mg}^{2+}+2 \mathrm{NaOH} \rightarrow \mathrm{Mg}(\mathrm{OH})_{2}+2 \mathrm{Na}^{+}
\end{gathered}
$$

As shown in Fig. 2(b), silica removal can also be conducted by coagulation using various salts such as iron [32], aluminum [26, 29, 35], and zinc [34]. Silica removal mechanism by coagulation is suggested to be adsorption, charge neutralization, enmeshment in a precipitate and inter-particle bridging, respectively. In similar way to softening, silica removal efficiency by coagulation depends mainly on solution $\mathrm{pH}$ because it regulates electrostatic attraction between silica and metal hydroxide. Hermosillia et al. [32] reported that the silica removal rate increased according to $\mathrm{pH}$ ranging from 5.5 to 10.5 under an optimized dosage of coagulants.

Softening and coagulation are able to treat large volumes of water at moderate cost. Occurrence of solid sludge and increase of conductivity by salt addition is the main operation issue of these chemical pretreatments. Specifically, residual aluminum and iron can cause insoluble metal precipitates in the RO unit. Therefore, both salt dosage and solution $\mathrm{pH}$ should be controlled properly according to water source properties in order to reduce the potential of RO fouling by insoluble metal silicates in the RO system [19, 41].

\subsection{Seed Precipitation/Aggregation}

Seeded precipitation is a widely used technique, especially for the supersaturated solution. The basic principle is the induction of the seed/silica agglomerate, and its scheme is depicted in Fig. 3. Silica gel and amorphous colloids have been the most investigated as the potential seed materials [42]. In brief, the introduction of the seed material to supersaturated solution generates higher concentrations of the precipitating species of silicic acid or colloidal silica near the seed material due to Van der Waals and electrostatic interactions. After adsorption onto active sites on the seed, polymerization proceeds for seed growth [43]. Bremere et al. [44] reported that $700 \mathrm{mg} / \mathrm{L}$ solutions of silicic acid were reduced to $100-150$ $\mathrm{mg} / \mathrm{L}$ at ambient temperature and neutral $\mathrm{pH}$ [44]. In addition, the presence of soluble iron with a concentration of $100 \mathrm{mg} / \mathrm{L}$ 

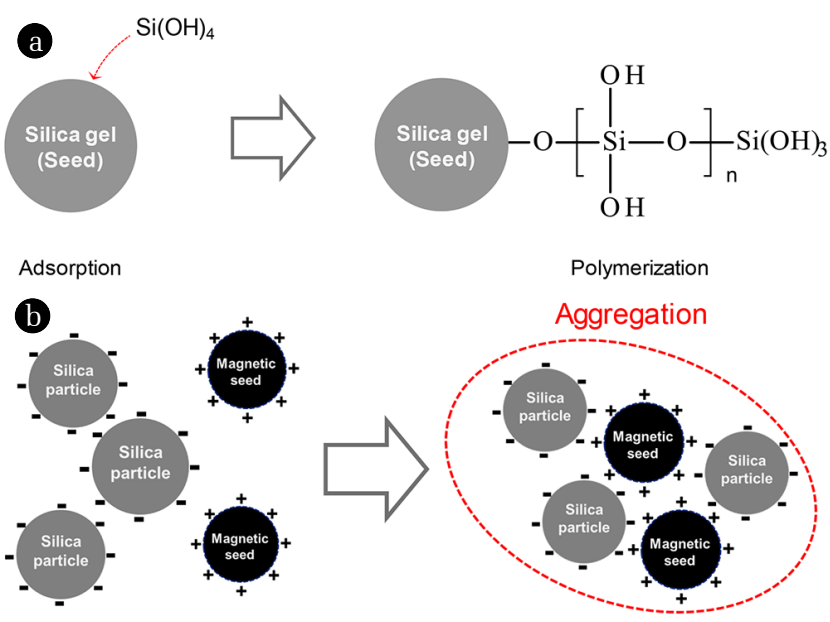

Separation by magnetic field

Fig. 3. Silica removal by using seed material. (a) Precipitation on silica gel, and (b) Aggregation with magnetic particles with opposite surface charge.

enhanced the silica reduction rate. Typically, the final concentration of silica in water after seeded precipitation will be similar to the saturation concentration.

Use of magnetic seed is another example of silica reduction using this aggregation principle. Chin et al. applied the magnetic nanoparticles to the chemical metal polishing (CMP) wastewater with high turbidity. Added seed particles rapidly formed aggregate with silica by electrostatic attraction and could be separated with the aid of a magnetic field [45].

Seeded precipitation/aggregation has been shown to be effective in the reduction of silica concentration above supersaturation to the saturation concentration. Seed properties such as the surface area and particle diameter determine the silica removal rate. Considering that sludge treatment can impose an operation issue, a proper recycling method is expected to extend its feasibility.

\subsection{Tight Ultrafiltration}

Colloidal silica can be removed by fine mechanical barriers such as ultrafiltration (UF). In particular, a tight UF membrane with a molecular weight cut-off (MWCO) range of approximately 10,000 Dalton can be used for the prefiltration of colloidal silica. As an example, a commercial polyethersulfone membrane was used for a thermal power and paper plant in India [46]. Each UF system has a total capacity of 3,840 and $6,000 \mathrm{~m}^{3} /$ day, respectively. In both projects, surface water was used as a feed for the high pressure boiler. This tight UF membrane achieved a colloidal silica removal rate of $99.8 \%$. Yang et al. [47] reported the more than 90\% removal of silica from chemical metal polishing (CMP) wastewater with a high silica level (above 1,000 mg/L) using tubular ceramic UF. Being compared with the polymeric membrane, the main advantage of a ceramic membrane is its robustness, which is suitable for harsh conditions such as intensive chemical cleaning. Although UF can only remove colloidal silica, it can reduce turbidity in the $\mathrm{RO}$ feed water without changing the conductivity or $\mathrm{pH}$.

Membrane fouling can be the main technical problem in the
UF treatment option. Experimental data suggested that the colloidal silica fouling was closely related to the zeta potential of the colloids [48], and ionic strength in the feed water [49]. In practice, membrane fouling by colloidal silica can be effectively mitigated via combination of frequent physical backwashing, chemically enhanced backwashes at regular intervals, and occasional cleaning in-place.

\subsection{Anion Exchange Resin}

Dissolved silica exists in equilibrium with bisilicate $\left(\mathrm{H}_{3} \mathrm{SiO}_{4}{ }^{-}\right)$ion as a very weak acid, and becomes more ionized at a higher $\mathrm{pH}$ value. Therefore, strong base anion (SBA) exchange resins in hydroxide form can be applied to remove dissolved silica (Fig. 4). As the ion exchange reaction proceeds, the local $\mathrm{pH}$ increases allowing the formation of $\mathrm{H}_{3} \mathrm{SiO}_{4}{ }^{-}$. This equilibrium shifts facilitates the removal of dissolved silica from water stream to matrix of ion exchange (IX) resin [50]. IX resin in the chloride form can only exchange anions for which it has a higher selectivity. Hence, IX resins in the chloride form have zero preference for silica because dissolved silica sparsely ionizes at neutral $\mathrm{pH}$ condition. In addition, it is generally postulated that IX resins provide some colloidal silica reduction through the filtration mechanism.

In a practical aspect, the IX process suffers from interference with other anionic species, leading to reduced efficiency for silica removal [51]. Nonetheless, silica removal by IX technique is effective when total dissolved solids concentration in the influent is low. Once exhausted, the IX resins can be regenerated using caustic soda, requiring additional cost and waste disposal. Silica probably polymerizes and stays on the resin due to the locally increased $\mathrm{pH}$, which makes the regeneration step slow. Hence, excess caustic soda and sufficient contact time are required for successful regeneration. Experimental study demonstrated that an increase in temperature strongly enhanced the regeneration efficiency [36].

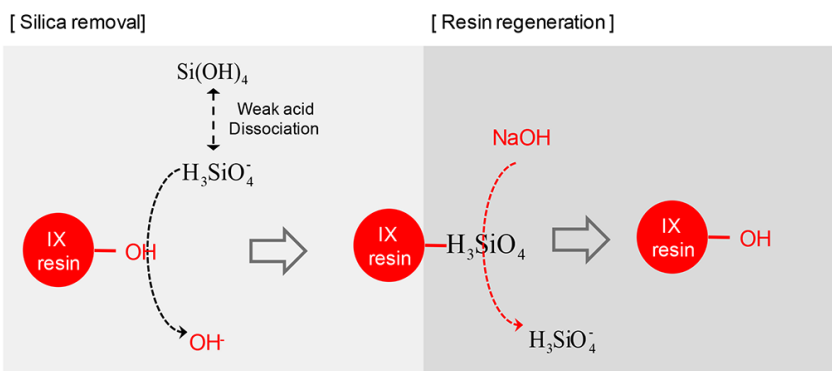

Fig. 4. Silica removal from water stream using ion exchange (IX) resin.

\subsection{Adsorbent Media}

Dissolved silica in the ionic form of $\mathrm{H}_{3} \mathrm{SiO}_{4}{ }^{-}$can be removed from the solution using metal oxide adsorbent such as activated alumina, goethite, and hematite. As represented in Fig. S1, these adsorbents has functional group of Metal - $\mathrm{O}-\mathrm{H}$ extending from the surface. The charge of these active sites may be cationic, neutral, or anionic, depending on the local $\mathrm{pH}$ condition. If the $\mathrm{pH}$ is below the point of zero charge, the adsorbent surface is positively charged, where the anionic species would interact strongly. Among various adsorbent media, aluminum compounds such as activated alumina have been investigated for silica reduction in RO brines due to its high 
adsorption capacity and selectivity to silica species. The silica adsorption performance was strongly dependent on solution $\mathrm{pH}$ and adsorbent dose. For example, silica removal rate about $90 \%$ was achieved for the activated alumina at optimum $\mathrm{pH}$ range of 8.0-8.5 [52].

The major technical issue of using adsorbent media is interference with other ionic species. Calcium and magnesium will also adsorb to alumina surfaces, and may compete with silica for adsorption sites [36]. Therefore, softening prior to adsorption with alumina can enhance silica removal efficiencies. On the other hand, Bouguerra et al. [52] reported that the presence of other ions such as sulfate, fluoride, nitrate, and hydrocarbonate, did not significantly decrease the amount of silica removed. After active sites are all exhausted, activated alumina adsorbent can be regenerated rapidly using caustic soda. In this case, change of surface chemistry such as the formation of aluminum silicate occurred, which affects the adsorption capacity [53]. Compared to IX resins, activated alumina adsorbents have higher silica selectivity and therefore, could be applied to brackish and geothermal waters. Example of commercial adsorbents has a 20-30 weight percentage capacity for silica. Water flow is a control parameter. Its empty bed contact time is reported to be in a range of $10-60 \mathrm{~min}$.

\subsection{Electro Coagulation}

Many literatures have suggested that electro coagulation (EC) is a promising technology for the removal of both dissolved $[54,55]$ and colloidal silica [56-58] in the various water streams. Its basic principle is in-situ generation of metal ion species by sacrificial anodic reaction (Fig. 5). The performance of an EC system is closely associated with following parameters; current density, charge loading, anode material, contact time, and system configuration including electrode arrangement. Anode of iron and aluminum are commonly used as the coagulant source. A bench scale study by Shulz et al. reported that aluminum was more effective than iron because $\mathrm{Al}$ and $\mathrm{Si}(\mathrm{OH})_{4}$ are effective mutual scavengers [59]. Specifically, the formation of stable hydroxyaluminosilicates (HAS) between dissolved silica and aluminum has been known as the main mechanism at neutral $\mathrm{pH}$ (Eq. (5)).

$$
\left[\mathrm{Al}(\mathrm{OH})_{3}\right]_{\mathrm{n}}+\mathrm{Si}(\mathrm{OH})_{4} \rightarrow(\mathrm{AlO})_{11}(\mathrm{SiO})_{\mathrm{n} / 2}(\mathrm{OH})_{2 \mathrm{n}}
$$

Den et al. [54] investigated the feasibility of EC with aluminum anode as a RO pretreatment process. When applied to the brackish water with total silica concentration of 80 to $120 \mathrm{mg} / \mathrm{L}$, silica removal efficiency up to $80 \%$ was achieved under a current intensity of 0.5 A with hydraulic retention time of $30 \mathrm{~min}$.

Colloidal silica usually carries a negative surface potential charge in both neutral and alkaline environments. Therefore, colloidal silica moves to the cathode, resulting in sludge accumulation on the electrode surface. To overcome this problem, the EC system generally adopts a bipolar configuration and periodically switches polar of the electrode. Den et al. achieved a removal efficiency of more than $95 \%$ in chemical mechanical polishing (CMP) wastewater using EC with an iron electrode [56]. They also mentioned the critical level of current density beyond which the removal efficiency gradually decreased. The basic silica removal principle

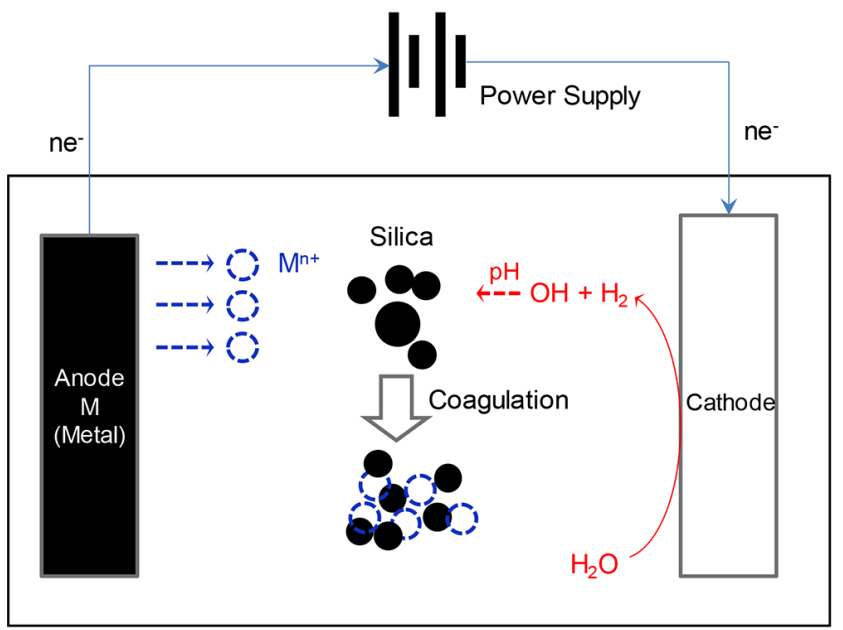

Fig. 5. Scheme of electro coagulation for silica removal. Sacrificial anode generates metal ion, resulting in coagulation of silica species including dissolved and colloidal formulation.

of EC is same at that of chemical coagulation. Therefore, the residual concentrations of aluminum or iron after EC treatment needs to be carefully monitored prior to the RO unit. Economic comparisons with chemical coagulation reported that EC has slightly higher initial capital costs, but significantly reduced operating costs. This cost reduction comes largely from the reduction of sludge disposal and labor [36].

\section{RO Operation Under High Silica Concentration}

In this section, we review the scale prevention in $\mathrm{RO}$ under silica rich condition. This challenge is also closely linked to RO operation at a higher recovery ratio. The technical strategy for this purpose includes antiscalants, RO operation under high/low $\mathrm{pH}$, and intermediate softening of $\mathrm{RO}$ concentrate.

\subsection{Silica Scale Inhibitor}

The dosing of silica specific antiscalants to the RO feed stream increases the threshold level of silica supersaturation for the onset of scaling [60]. As a result, RO plant can maintain its designed recovery rate in a safe way. For an example of field application, Darton reported stable RO operation for more than two years using commercially available antiscalant [61]. Silica concentration in the reject stream increased up to $340 \mathrm{mg} / \mathrm{L}$. Inhibition and dispersion have been reported to be the mechanisms of these silica controlling agents [4]. Inhibition prevents polymerization of soluble silicates, which keeps the silica soluble. Meanwhile, dispersants inhibit the agglomeration and deposition of foulants onto the membrane surface through electrostatic repulsion [62, 63]. The main advantage of this chemical approach is the relatively simple process configuration. Antiscalants are added prior to the static mixer or cartridge filter housing after simple pretreatment such as activated carbon and multimedia filtration. On the other hand, the usage of antiscalant increases the operation cost for water production and over dosing has the potential risk of organic and biological 
fouling [64]. The concentration of other metal ions in the feed water also should be considered when using the antiscalants. For example, Weng proposed the guideline for commercial polymeric dispersant reflecting the magnesium, iron, and aluminum levels in the feed water, based on three pilot RO studies [62]. In addition, antiscalant containing phosphoric acid/phosphonate groups have the potential risk of not being effective against aluminosilicates, due to the precipitation reaction with residual aluminum in the RO feed [41].

At last, we briefly presented a practice of industrial desalination applying silica inhibitors. Fabrication plant (FAB) for electric device was newly constructed in Philippines. The electronic FAB has the deionized (DI) water system with capacity of $10,000 \mathrm{~m}^{3}$ day (Fig. S2). DI water with resistivity of $10 \mathrm{M} \Omega$ is produced and transported to the manufacturing facilities. Quality of groundwater used for system design was summarized in Table S1. Especially, silica level in raw water was analyzed in the range of $55.9-110 \mathrm{mg} / \mathrm{L}$, raising potential risk of silica scaling in RO process. Pretreatment consists of multimedia filtration and activated carbon filter to remove the turbidity and organic carbon content. Silica is hardly removed in this pretreatment process. Instead, commercial product of silica specific scale inhibitor was injected to the $1^{\text {st }}$ RO block. $\mathrm{pH}$ of RO feed water was adjusted to 8.4 using caustic soda according to the chemical vendor's guideline. The final concentration of silica inhibitor was set to $5.4 \mathrm{mg} / \mathrm{L}$ in the $\mathrm{RO}$ feed side. RO reject stream containing concentrated silica up to $366 \mathrm{mg} / \mathrm{L}$ was transported to the wastewater treatment plant.

\subsection{RO Operation at Alkaline $\mathrm{pH}$ Condition}

As previously discussed in Section 2, silica solubility shows exponential increase beyond $\mathrm{pH} 10$. Therefore, $\mathrm{RO}$ operation at elevated $\mathrm{pH}$ can allow silica in the concentrate stream to retain soluble state instead of polymerization. Higher $\mathrm{pH}$ also can effectively control biological, organic, and particulate RO fouling. Simultaneously, the silica and boron rejection rates are substantially higher than conventional RO operations by the negatively charged membrane [65]. However, alkali feeding conditions are liable to cause the scale formation by hardness and metal ions such as iron and manganese. Hence, the main design feature is the multiple pretreatment processes to achieve extreme reduction of the hardness and metal ions [66].

Some proprietary processes for industrial pure water treatment have been developed based on this principle of high $\mathrm{pH}$ RO operation $[10,67]$. For example, HERO ${ }^{\mathrm{TM}}$ implements a caustic injection to raise feed $\mathrm{pH}$ to $10-11$ before it flows to the $\mathrm{RO}$ unit. Its pretreatment block consists of softening to remove hardness, weak acid cation exchange to remove alkalinity, acidification to convert residual alkalinity to $\mathrm{CO}_{2}$, and degasification to remove dissolved $\mathrm{CO}_{2}$ (Fig. 6(a)). In an example of OPUS ${ }^{\circledR}$ technology, pretreatment has a sequence of chemical softening/thickening, filtration, and ion exchange ahead of the RO unit (Fig. 6(b)). Previous studies of RO plant adopting HERO ${ }^{\mathrm{TM}}$ reported the stable operation for 1 year with an $85 \%$ recovery for feed water containing of 50 $\mathrm{mg} / \mathrm{L}$ of silica. [36, 68]. Another industrial practice of $\mathrm{HERO}^{\mathrm{TM}}$ system also reported stable daily production of $146 \mathrm{~m}^{3}$ of de-ionized water for the manufacturing of display panel, achieving total RO recovery rate of $90 \%$. Commercial operation data was summarized in Table S2.

Due to the feed water virtually devoid of hardness ion and much increased silica solubility, $\mathrm{RO}$ operation at higher $\mathrm{pH}$ can achieve RO recovery of beyond 85 \% even with a high silica concentrate. Meanwhile, multiple pretreatments lead to a complicated operation and raise cost, which may not suitable to applying in large desalination plants [43, 69].

\subsection{RO Operation at Acidic $\mathrm{pH}$ Condition}

Silica polymerization plays an important role in scale layer formation. At low $\mathrm{pH}$, silica polymerization rate is considerably retarded because silicic acid virtually does not dissociate into silicate anion. Ning and coworkers studied the mitigation of silica scale at acidic $\mathrm{pH}$ [70]. By reducing $\mathrm{pH}$ to less than 4.5 with an antiscalant, seawater RO system recoveries in the $85-90 \%$ range were achievable with $\mathrm{RO}$ concentrate for total silica concentrations exceeding 1,000 $\mathrm{mg} / \mathrm{L}$. However, the individual effect of low $\mathrm{pH}$ and antiscalant was not clarified. In similar way, Bush et al. reported that silica scaling were negligible up to $600 \mathrm{mg} / \mathrm{L}$ in the condition of feed water $\mathrm{pH}$ less than 5 or higher than 10 . In more detail, total amount of soluble silica at $\mathrm{pH} 4,10$, and 11 were relatively constant, indicating that negligible polymerization at these $\mathrm{pH}$ conditions [71]. The RO operation at low $\mathrm{pH}$ also can be advantageous in reducing the potential for scale from hardness ions such as calcium and magnesium. RO rejection is directly related to the ionic charge on target species. Therefore, decrease extent of silicic acid ionization at this low $\mathrm{pH}$ cause the relative high level of silica in the RO filtrate, which can be a subsequent issue for high grade water production.

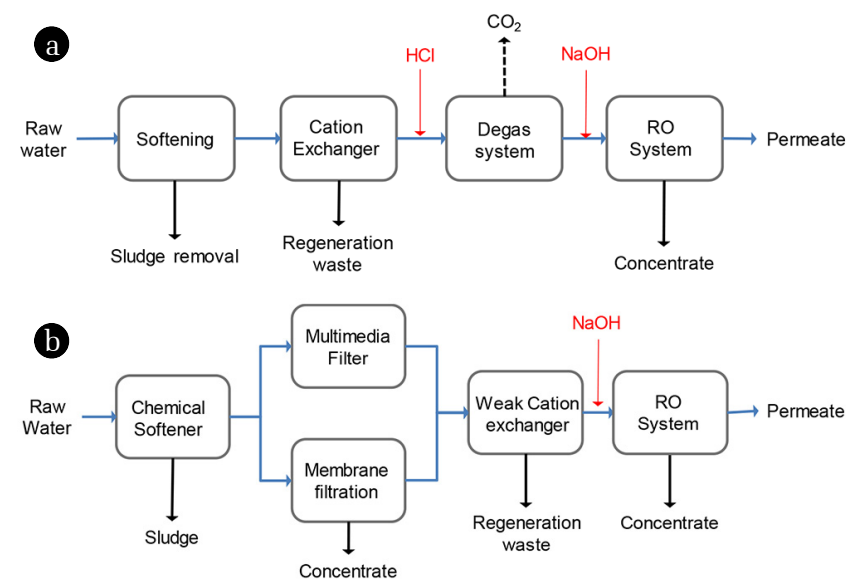

Fig. 6. Process configuration of proprietary systems adopting RO operation at alkaline $\mathrm{pH}$ condition. (a) High Efficiency Reverse Osmosis $\left(\mathrm{HERO}^{\mathrm{TM}}\right)$, (b) Optimized Pretreatment and Unique Separation $\left(\right.$ OPUS $\left.^{\mathrm{TM}}\right)$.

\subsection{Intermediate Softening of RO Concentrate}

Industrial RO system usually adopts multistage configuration, where the concentrate from the primary stage flows to the next stage as feed. The basic concept of intermediate softening is the recycling of RO concentrate from previous stage after removal of scaling minerals. Various options, such as chemical precipitation [72], seeded precipitation [73], ion exchange [74] and electro coagulation [72], 


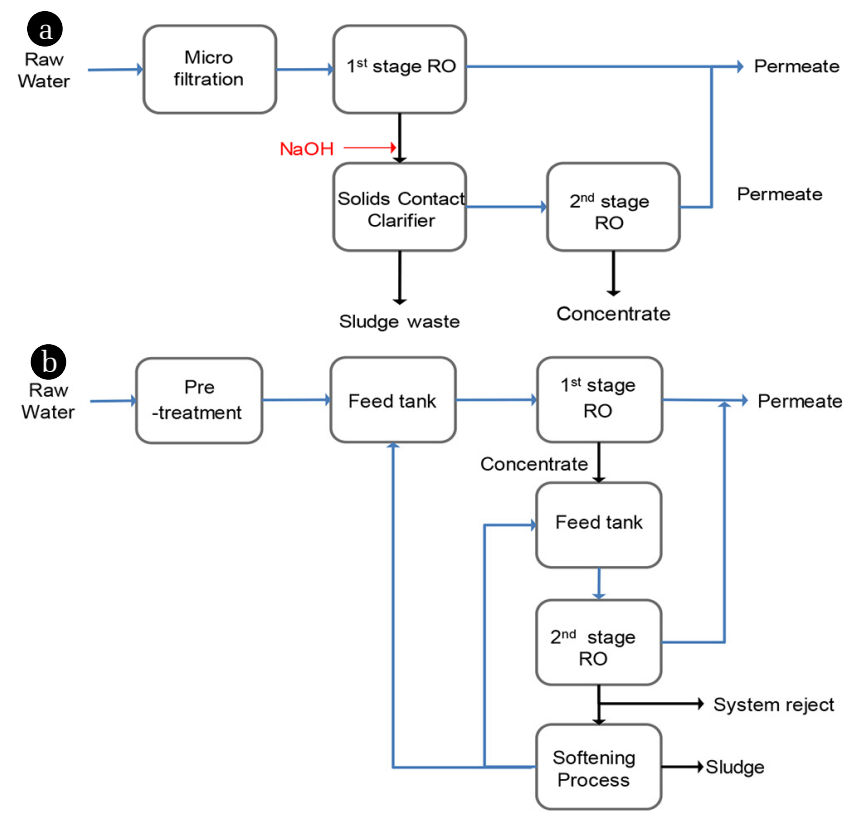

Fig. 7. Process flow of (a) Intermediate chemical demineralization (ICD) using solids contact clarifier [75]. (b) Advanced Recovery Reverse Osmosis Water Technology (ARROW ${ }^{\mathrm{T} M}$ ).

are available for concentrate treatment. As presented in Fig. 7(a), Gabelich et al. suggested a two-stage process where the $1^{\text {st }} \mathrm{RO}$ concentrate was treated by intermediate chemical demineralization (ICD) prior to the $2^{\text {nd }}$ RO. 9-month pilot study reported that silica removal efficiency of $67 \%$ by ICD enhanced the overall water recovery by up to $95 \%[75,76]$.

A couple of proprietary technologies have been developed based on this principle. As an example, ARROW ${ }^{\mathrm{TM}}$ adopts the softening of the $2^{\text {nd }}$-stage $\mathrm{RO}$ concentrate and appropriate flow is recycled to the feed tank to make the blend with the $1^{\text {st }}$-stage $\mathrm{RO}$ concentrate and pretreated raw water. Chemical precipitation and strong acidic cation exchange resins are generally used as a softening process. $[37,74]$. Final reject stream line containing RO concentrate and clarifier/ion exchange waste is sent for waste treatment such as a solar evaporator. The total volume of reject stream is less than $5 \%$, giving an overall process recovery of higher than $95 \%$.

Intermediate softening of RO concentrate allows extremely high system recovery. Meanwhile, the complex system configuration requires skilled operation. Simultaneously, long-term system performance needs to be fully established. Quantities of sludge from intermediate softening stage impose a major challenge on its economic feasibility including disposal cost. Therefore, compact and cost effective softening for $\mathrm{RO}$ concentrate is thought to be suitable in this approach.

\section{Summary and Conclusions}

Silica is ubiquitous in natural water source and its scale deteriorates industrial RO performance. In this literature review, we provided the comprehensive information on the silica treatment methods currently available for industrial desalination. Silica takes various states with different properties and develops scaling on the RO

Table 1. Summary of Silica Treatment Technologies Currently Available for Industrial Desalination

\begin{tabular}{|c|c|c|c|c|c|}
\hline Strategy & Technology & Principles & Issues to be considered & Operation features & Ref. \\
\hline \multirow{6}{*}{$\begin{array}{l}\text { Feed water } \\
\text { pretreatment }\end{array}$} & $\begin{array}{l}\text { Softening/ } \\
\text { Coagulation }\end{array}$ & $\begin{array}{l}\text { - Adsorption/Co-precipitation by metal } \\
\text { salts addition and pH control }\end{array}$ & $\begin{array}{l}\text { - Disposal of chemical sludge } \\
\text { - Increase of conductivity, pH, and } \\
\text { residual metals in the RO feed }\end{array}$ & $\begin{array}{l}\text { - Removal efficiency : > 90\% } \\
\text { - pH : alkaline (10-11) }\end{array}$ & $\begin{array}{l}{[7],} \\
{[32]}\end{array}$ \\
\hline & $\begin{array}{l}\text { Seed precipitation } \\
\text { /aggregation }\end{array}$ & $\begin{array}{l}\text { - Seed/silica agglomerate under saturation } \\
\text { condition }\end{array}$ & $\begin{array}{l}\text { - Applicable in silica supersaturation } \\
\text { - Seed material property }\end{array}$ & $\begin{array}{l}\text { - Reduction of silica } \\
\quad: 700 \rightarrow 100-150 \mathrm{mg} / \mathrm{L}\end{array}$ & $\begin{array}{l}{[44],} \\
{[45]}\end{array}$ \\
\hline & Tight ultrafiltration & $\begin{array}{l}\text { - Size exclusion of colloidal silica using } \\
\text { commercial membrane }\end{array}$ & $\begin{array}{l}\text { - Applicable to colloidal silica } \\
\text { - Membrane Cleaning }\end{array}$ & $\begin{array}{l}\text { - Removal efficiency : > } 90 \% \\
\text { - MWCO : 10,000 Dalton }\end{array}$ & {$[47]$} \\
\hline & Ion exchange & - Exchange of silicate with hydroxide ion & $\begin{array}{l}\text { - Interference with other anions } \\
\text { - Resin regeneration }\end{array}$ & $\begin{array}{l}\text { - Effective only in strong base anionic } \\
\text { resin }\end{array}$ & {$[51]$} \\
\hline & Adsorbent media & $\begin{array}{l}\text { - Sorption of silica on adsorbent such as } \\
\text { activated alumina }\end{array}$ & $\begin{array}{l}\text { - Interference with other ion species } \\
\text { - Change of media surface }\end{array}$ & $\begin{array}{l}\text { - Optimum pH : 8.0-8.5 } \\
\text { - Removal efficiency: about 90\% }\end{array}$ & {$[52]$} \\
\hline & Electro-coagulation & $\begin{array}{l}\text { - Generation of metal coagulants by } \\
\text { sacrifice anode } \\
\text { - Less sludge production than chemical } \\
\text { treatment }\end{array}$ & $\begin{array}{l}\text { - Increase in capital investment } \\
\text { - Residual metal ion such as Al, Fe in } \\
\text { the feed stream to RO }\end{array}$ & $\begin{array}{l}\text { - Removal efficiency } \\
\text { : 80\% (dissolved), 95\% (colloidal) }\end{array}$ & {$[54]$} \\
\hline \multirow{4}{*}{$\begin{array}{l}\text { RO operation } \\
\text { under high } \\
\text { silica conc }\end{array}$} & Scale inhibitor & $\begin{array}{l}\text { - Chemicals which inhibit silica polymerization } \\
\text { or scale particle aggregation }\end{array}$ & $\begin{array}{l}\text { - Exact dosing control } \\
\text { - Environmental regulation for silica and } \\
\text { antiscalant }\end{array}$ & $\begin{array}{l}\text { - Antiscalant dose: } 4-12.5 \mathrm{ppm} \\
\text { - RO recovery : } 50-75 \%\end{array}$ & {$[62]$} \\
\hline & $\begin{array}{l}\text { Operation } \\
\text { at alkaline } \mathrm{pH}\end{array}$ & $\begin{array}{l}\text { - Increase of silica solubility in the } \\
\text { concentrate stream (pH: 10-11) }\end{array}$ & $\begin{array}{l}\text { - Multiple pretreatment to remove } \\
\text { hardness }\end{array}$ & - RO recovery: $85 \%$ & {$[65]$} \\
\hline & $\begin{array}{l}\text { Operation } \\
\text { at acidic pH }\end{array}$ & $\begin{array}{l}\text { - Retardation of silica polymerization at } \\
\text { low pH condition (pH: 4-5) }\end{array}$ & - Decrease of silica rejection rate & - RO recovery : 84-96\% & {$[70]$} \\
\hline & $\begin{array}{l}\text { Intermediate } \\
\text { softening }\end{array}$ & $\begin{array}{l}\text { - Silica removal in the concentrate stream } \\
\text { before feeding to next RO stage }\end{array}$ & $\begin{array}{l}\text { - Complex system configuration } \\
\text { - Compact and rapid silica removal from } \\
\text { RO concentrate }\end{array}$ & - RO recovery : up to $95 \%$ & {$[75]$} \\
\hline
\end{tabular}


membrane surface through complex mechanisms. Solution chemistry also significantly affects the silica scaling. For these reasons, effective silica control in desalination $\mathrm{RO}$ can be achieved in a number of different ways. As summarized in Table 1, each technique has its own operating principles and features.

Pretreatment protects RO from silica scaling through direct reduction of silica in feed water. However, each silica pretreatment option also has application issues, such as solid sludge and chemical waste, which inevitably originate from its operation principle Thus, it is important to select a suitable method according to the raw water conditions such as major silica species and total concentration. In addition, pretreatment methods except UF inevitably changes the water condition by $\mathrm{pH}$ adjustment or chemical dosing for the optimal performance of silica removal. Therefore, the change of water quality after pretreatment should be carefully evaluated in aspects of subsequent RO filtration.

It is also possible to mitigate scale formation via regulating silica chemistry in RO system. In detail, this strategy increases solubility limit or inhibit polymerization / agglomeration of silica species. Antiscalant dosing and $\mathrm{pH}$ adjustment of $\mathrm{RO}$ feed can maintain the design recovery rate even in the silica saturation stream. It is necessary to note that the alkaline $\mathrm{pH}$, which inhibits silica scale, can easily facilitate carbonate scale or metal precipitation. Therefore, the characteristics of raw water should be considered in a comprehensive manner.

A more recent emerging trend focuses on the achieving the extremely high RO recovery rate up to $90 \%$. For this purpose, $\mathrm{RO}$ concentrate is further treated and recycled to the feed stream instead of discharge. Despite of advantage in water recovery rate, complex configuration required skilled operation of overall system. Technical bottleneck for this concentrate recycling mainly derived from interference between the main RO block and the intermediate concentrate treatment for recycling. Concentration of silica and other scale components are proportional to the RO recovery rate. Therefore, adopting compact unit silica treatment such as seed material, adsorbent and elector coagulation will effectively extend the applicability of this concentrate recycling approach.

In addition to literature review on silica scaling, we briefly presented two cases of commercial RO operation employing silica control techniques (scale inhibitor and high $\mathrm{pH}$ operation). In both cases, RO system stably produced DI water for the usage in manufacturing electronic devices. Feasible silica control technology can be determined considering whole configuration desalination processes as well as silica level contained in the feed water. For instance, direct control of silica scale in RO skid would be more effective approach rather than pretreatment when only the silica was the main scalant in the water source used. At the same time, on-site applicability of silica treatment technique needs to be evaluated over years considering facility operation (i.e. waste \& chemical management) and water production cost.

\section{Author Contributions}

Y-M.P. (Ph.D candidate) wrote the manuscript. K-M.Y. (ph. D) adviced about the manuscript. C-H.P. (professor) supervised the thesis.

\section{References}

1. Al-Rehaili AM. Comparative chemical clarification for silica removal from RO groundwater feed. Desalination 2003;159: 21-31.

2. Gorzalski AS, O Coronell. Fouling of nanofiltration membranes in full-and bench-scale systems treating groundwater containing silica. J. Membr. Sci. 2014;468:349-359.

3. Sheikholeslami R, Bright J. Silica and metals removal by pretreatment to prevent fouling of reverse osmosis membranes. Desalination 2002;143:255-267.

4. Neofotistou E, KD Demadis. Use of antiscalants for mitigation of silica (SiO2) fouling and deposition: fundamentals and applications in desalination systems. Desalination 2004;167:257-272.

5. Ning RY. Discussion of silica speciation, fouling, control and maximum reduction. Desalination 2003;151:67-73.

6. Lisitsin D, Hasson D, Semiat R. Critical flux detection in a silica scaling RO system. Desalination 2005;186:311-318.

7. Sheikholeslami R, Al-Mutaz I, Koo T, Young A. Pretreatment and the effect of cations and anions on prevention of silica fouling. Desalination 2001;139:83-95.

8. Tong T, Wallace AF, Zhao S, Wang Z. Mineral scaling in membrane desalination: Mechanisms, mitigation strategies, and feasibility of scaling-resistant membranes. J. Membr. Sci. 2019;579:52-69.

9. Li Y, Li M, Xiao K, Huang X. Reverse osmosis membrane autopsy in coal chemical wastewater treatment: Evidences of spatially heterogeneous fouling and organic-inorganic synergistic effect. J. Clean. Prod. 2019;246:118964.

10. Wang YN, X Li, R Wang. Silica scaling and scaling control in pressure retarded osmosis processes. J. Membr. Sci. 2017;541:73-84

11. Ning RY. Reactive silica in natural waters - A review. Desalin. Water Treat. 2010; 21:79-86.

12. Sheikholeslami R, Tan S. Effects of water quality on silica fouling of desalination plants. Desalination 1999;126:267-280.

13. Koo T, Lee Y, Sheikholeslami R. Silica fouling and cleaning of reverse osmosis membranes. Desalination 2001;139:43-56.

14. Iler R. The Chemistry of Silica: solubility, polymerization, colloid and surface properties, and biochemistry. A Wiley-Interscience publication; 1979.

15. Alexander GB, W Heston, RK Iler. The solubility of amorphous silica in water. J. Phys. Chem. 1954;58:453-455.

16. Chan S. A review on solubility and polymerization of silica. Geothermics 1989;18:49-56.

17. Semiat R, Sutzkover I, Hasson D. Scaling of RO membranes from silica supersaturated solutions. Desalination 2003;157:169-191.

18. Tong T, Zhao S, Boo C, Hashmi SM, Elimelech M. Relating silica scaling in reverse osmosis to membrane surface properties. Environ. Sci. Technol. 2017;51:4396-4406.

19. Gabelich CJ, Chen WR, Yun TI, Coffey BM. The role of dissolved aluminum in silica chemistry for membrane processes. Desalination 2005;180:307-319.

20. Al-Ahmad M, Aleem FA, Mutiri A, Ubaisy A. Biofuoling in RO membrane systems Part 1: Fundamentals and control. Desalination 2000;132:173-179.

21. Sheikholeslami R, Zhou S. Performance of RO membranes in 
silica bearing waters. Desalination 2000;132:337-344.

22. Piyadasa C, Ridgway HF, Yeager TR, et al. The application of electromagnetic fields to the control of the scaling and biofouling of reverse osmosis membranes-A review. Desalination 2017;418:19-34.

23. Kimura K, Okazaki S, Ohashi T, Watanabe Y. Importance of the co-presence of silica and organic matter in membrane fouling for RO filtering MBR effluent. J. Membr. Sci. 2016;501:60-67.

24. Quay AN, Tong T, Hashmi SM, Zhou Y, Zhao S, Elimelech M. Combined Organic Fouling and Inorganic Scaling in Reverse Osmosis: Role of Protein-Silica Interactions. Environ. Sci. Technol. 2018;52:9145-9153.

25. Al-Mutaz IS, Al-Anezi IA. Silica removal during lime softening in water treatment plant. In International Conference on Water Resources \& Arid Environment. 2004. King Saud University Riyadh.

26. Chen S, Chang T, Lin C. Silica pretreatment for a RO brackish water source with high magnesium. Water Sup. 2006;6:179-187.

27. Hsu HD, Chen SS, Lin CL, Chang TC. Silica pretreatment for RO membrane by softening-adsorption. J. Environ. Eng. Manage. 2008;18:99-103.

28. Sahinkaya E, Sahin A, Yurtsever A, Kitis M. Concentrate minimization and water recovery enhancement using pellet precipitator in a reverse osmosis process treating textile wastewater. J Environ. Manage. 2018;222:420-427.

29. Chuang S, Chang TC, You SJ, Ouyang CF. Evaluation of wastewater reclamation processes in a high-tech industrial park. Desalination 2005;175:143-152.

30. Ho JS, Ma Z, Qin J, Sim SH, Toh CS. Inline coagulation-ultrafiltration as the pretreatment for reverse osmosis brine treatment and recovery. Desalination 2015;365: 242-249.

31. Cheng HH, SS Chen, SR Yang. In-line coagulation/ultrafiltration for silica removal from brackish water as RO membrane pretreatment. Sep. Purif. Technol. 2009;70:112-117.

32. Hermosilla D, Ordóñez R, Blance L, Fuente E, Blanco A. pH and particle structure effects on silica removal by coagulation. Cnem. Eng. Technol. 2012;35:1632-1640.

33. Latour I, Miranda R, Carceller R, Blanco A. Efficiency of polyaluminum nitrate sulfate-polyamine hybrid coagulants for silica removal. Desalin. Water Treat. 2016;57:17973-17984.

34. Zeng Y, Yang C, Pu W, Zhang X. Removal of silica from heavy oil wastewater to be reused in a boiler by combining magnesium and zinc compounds with coagulation. Desalination 2007;216: 147-159.

35. Latour I, Miranda R, Blanco A. Silica removal from newsprint mill effluents with aluminum salts. Chem. Eng. J. 2013;230: 522-531.

36. Milne NA, O'Reilly T, Sanciolo P, et al. Chemistry of silica scale mitigation for $\mathrm{RO}$ desalination with particular reference to remote operations. Water Res. 2014;65:107-133.

37. Ning RY, Tarquin A, Trzcinski M, Patwardhan G. Recovery optimization of RO concentrate from desert wells. Desalination 2006;201:315-322.

38. Nurdogan Y, Goldman E, Dawes S. Optimizing chemical treatment of a power plant water softener. Water Sci. Technol. 1998;38:347-354.

39. Latour I, Miranda R, Blanco A. Silica removal in industrial effluents with high silica content and low hardness. Environ. Sci. Pollut. R. 2014;21:9832-9842.

40. Latour I, Miranda R, Blanco A. Silica removal with sparingly soluble magnesium compounds. Part I. Sep. Perif. Technol. 2014;138:210-218.

41. Gabelich CJ, Ishida KP, Gerringer FW, Evangelista R, Kalyan M. Control of residual aluminum from conventional treatment to improve reverse osmosis performance. Desalination 2006;190:147-160.

42. Sugita H, Matsunaga I, Yamaguchi T, Kato K, Ueda A. Silica removal performance of seed from geothermal fluids. Geothermics 2003;32:171-185.

43. Liu Q, Xu GR, Das R. Inorganic scaling in reverse osmosis (RO) desalination: Mechanisms, monitoring, and inhibition strategies. Desalination 2019;468:114065.

44. Bremere I, Kennedy M, Mhyio S, Jaljuli A, Witkamp GJ, Schippers J. Prevention of silica scale in membrane systems: removal of monomer and polymer silica. Desalination 2000;132:89-100.

45. Chin CJM, Chen PW, LJ Wang. Removal of nanoparticles from $\mathrm{CMP}$ wastewater by magnetic seeding aggregation. Chemosphere 2006;63:1809-1813.

46. Silica removal projects in india use hollow-fibre membrane. Membr. Technol. 2012;2012:6.

47. Yang GC, Li CJ. Electrofiltration of silica nanoparticle- containing wastewater using tubular ceramic membranes. Sep. Purif. Technol. 2007;58:159-165.

48. Singh G, Song L. Experimental correlations of $\mathrm{pH}$ and ionic strength effects on the colloidal fouling potential of silica nanoparticles in crossflow ultrafiltration. J. Membr. Sci. 2007;303:112-118.

49. Singh G, Song L. Cake compressibility of silica colloids in membrane filtration processes. Ind. Eng. Chem. Res. 2006;45: 7633-7638.

50. Meyers P, Behavior of silica in ion exchange and other systems. IWC. 1999;99:64.

51. Ali MBS, Hamrouni B, Bouguecha S, Dhahbi M. Silica removal using ion-exchange resins. Desalination 2004;167:273-279.

52. Bouguerra W, Ali MBS, Hamrouni B, Dhahbi M. Equilibrium and kinetic studies of adsorption of silica onto activated alumina Desalination 2007;206:141-146.

53. Sanciolo P, Milne N, Taylor K, Mullet M, Gray S. Silica scale mitigation for high recovery reverse osmosis of groundwater for a mining process. Desalination 2014;340:49-58.

54. Den W, Wang CJ. Removal of silica from brackish water by electrocoagulation pretreatment to prevent fouling of reverse osmosis membranes. Sep. Purif. Technol. 2008;59:318-325.

55. Liao Z, Gu Z, Schulz MC, Davis JR, Baygents JC, Farrell J. Treatment of cooling tower blowdown water containing silica, calcium and magnesium by electrocoagulation. Water Sci. Technol. 2009;60:2345-2352.

56. Den W, Huang C. Electrocoagulation for removal of silica nano-particles from chemical-mechanical-planarization wastewater. Colloids. Surf. A. Physicochem. Eng. Asp. 2005;254:81-89.

57. Den W, Huang C, Ke HC. Mechanistic study on the continuous flow electrocoagulation of silica nanoparticles from polishing wastewater. Ind. Eng. Chem. Res. 2006;45:3644-3651. 
58. Den W, Huang C. Parameter optimization and design aspect for electro-coagulation of silica nano-particles in wafer polishing wastewater. Water Sci. Technol. 2006;53:187-194.

59. Schulz M, Baygents JC, Farrell J. Laboratory and pilot testing of electrocoagulation for removing scale-forming species from industrial process waters. Int. J. Environ. Sci. Tech. 2009;6: 521-526.

60. Semiat R, Sutzkover I, Hasson D. Characterization of the effectiveness of silica anti-scalants. Desalination 2003;159:11-19.

61. Darton E. RO plant experiences with high silica waters in the Canary Islands. Desalination 1999;124:33-41.

62. Weng PF. Silica scale inhibition and colloidal silica dispersion for reverse osmosis systems. Desalination 1995;103:59-67.

63. Badruzzaman M, Voutchkov N, Weinrich L, Jacangelo JG. Selection of pretreatment technologies for seawater reverse osmosis plants: A review. Desalination 2019;449:78-91.

64. Turek M, Mitko K, Piotrowski K, Dydo P. Laskowska E, Jakóbik-Kolon A. Prospects for high water recovery membrane desalination. Desalination 2017;401:180-189.

65. Franks R, Bartels C, Nagghappan L. Performance of a reverse osmosis system when reclaiming high $\mathrm{pH}$-high temperature wastewater. In Proceedings of the American Water Works Association Membrane Technology Conference, Memphis, TN. 2009.

66. Subramani A, Schlicher R, Long J, Yu J, Lehman S, Jacangelo JG. Recovery optimization of membrane processes for treatment of produced water with high silica content. Desalin. Water Treat. 2011;36:297-309.

67. Loganathan K, Chelme-Ayala P, El-Din MG. Pilot-scale study on the reverse osmosis treatment of oil sands tailings pond water: Impact of pretreatment on process performance. Desalination 2015;360:52-60.
68. Vani N, J Kasper, Rega C. HERO ${ }^{\mathrm{TM}}$ application on high silica gray water for an ACC combined cycle power plant. In 63rd International Water Conference Annual Meeting. 2002.

69. Singh R. Fleming H. Enhancing desalination processes: Recovery with hybrid membranes. Filtr. Separat. 2009;46:10-12.

70. Ning RY, Tarquin AJ, Balliew JE. Seawater RO treatment of RO concentrate to extreme silica concentrations. Desalin. Water Treat. 2010;22:286-291.

71. Bush JA, Vanneste J, Gustafson EM, et al. Prevention and management of silica scaling in membrane distillation using $\mathrm{pH}$ adjustment. J. Membr. Sci. 2018;554:366-377.

72. Subramani A, Cryer E, Liu L, Lehman S, Ning RY, Jacangelo JG. Impact of intermediate concentrate softening on feed water recovery of reverse osmosis process during treatment of mining contaminated groundwater. Sep. Purif. Technol. 2012;88: 138-145.

73. Rahardianto A, Gao J, Gabelich CJ, Williams MD, Cohen Y. High recovery membrane desalting of low-salinity brackish water: integration of accelerated precipitation softening with membrane RO. J. Membr. Sci. 2007;289:123-137.

74. Pérez-González A, Urtiaga AM, Ibáñez R, Ortiz I. State of the art and review on the treatment technologies of water reverse osmosis concentrates. Water Res. 2012;46:267-283.

75. Gabelich CJ, Williams MD, Rahardianto A, Franklin JC, Cohen Y. High-recovery reverse osmosis desalination using intermediate chemical demineralization. J. Membr. Sci. 2007;301: 131-141.

76. Gabelich CJ, Rahardianto A, Northrup CR, Yun TI, Cohen Y. Process evaluation of intermediate chemical demineralization for water recovery enhancement in production-scale brackish water desalting. Desalination 2011;272:36-45. 